POLIBETÁNICA

Núm. 39, pp. 91-101. México, 2015

\title{
ANTIBACTERIAL ACTIVITY OF SOME MEDICINAL EUPATORIUM SPECIES AGAINST ANTIBIOTIC RESISTANT PATHOGENIC BACTERIA
}

\section{ACTIVIDAD ANTIBACTERIANA DE ALGUNAS ESPECIES MEDICINALES DE EUPATORIUM CONTRA BACTERIAS PATÓGENAS RESISTENTES A ANTIBIÓTICOS}

\author{
Edgar García-Sánchez, César B. Ramírez-López, Rosa E. Martínez-Muñoz, \\ Alberto Flores-García, Rosa E. del Río, y Mauro M. Martínez-Pacheco \\ Instituto de Investigaciones Químico Biológicas, Universidad Michoacana de San Nicolás \\ de Hidalgo, Ed. B-3, Ciudad Universitaria, Morelia, Michoacán 58030, Mexico. \\ Correo electrónico: mpacheco@umich.mx
}

\begin{abstract}
Thirty six samples arising from hexane, dichloromethane, and methanol extracts from four medicinal Eupatorium species were screened against Gram positive and Gram negative resistant bacteria associated with nosocomial infections by disk diffusion method. The best antibacterial extracts were selected by correspondence analysis. The hexane extracts showed high inhibition against clinical isolated bacteria. The qualitative chemical analysis was realized in the best antibacterial hexane extracts. The main components identified were triterpenes and benzopyran compounds which of extensively had been reported their antibacterial activities. Our results showing that medicinal Eupatorium species studied in this work have metabolites secondary antibacterial particularly against antibiotic resistant strains, Klebsiella pneumoniae and Staphylococcus aureus and validate their uses in traditional medicine.
\end{abstract}

Key words: Eupatorium, antibacterial, secondary metabolites, $K$. pneumoniae, S. aureus.

\section{RESUMEN}

Treinta y seis extractos hexánicos, diclorometanólicos y metanólicos de cuatro especies medicinales de Eupatorium fueron ensayados contra bacterias resistentes Gram positivas y Gram negativas asociadas con infecciones nosocomiales por el método de difusión en disco. Los mejores extractos antibacterianos fueron seleccionados por un análisis de correspondencia. Los extractos hexánicos mostraron mejor inhibición de los aislados clínicos. El análisis químico cualitativo fue realizado a los extractos con mejor actividad antibacteriana. Los principales componentes identificados fueron triterpenos y benzopiranos los cuales han sido extensamente reportados por sus actividades antibacterianas. Nuestros resultados muestran que las especies medicinales de Eupatorium estudiadas en este trabajo tienen metabolitos secundarios antibacterianos contra bacterias resistentes a antibióticos tales como, Klebsiella pneumoniae y Staphylococcus aureus, y se validan sus usos en la medicina tradicional. 
Palabras clave: Eupatorium, antibacteriano, metabolito secundario, $K$. pneumoniae, $S$. aureus.

\section{INTRODUCTION}

In Mexico, the increased incidence of nosocomial infections by multi-drug resistant bacteria is a health problem with approximately 35000 annual cases. All cases have epidemiologic importance, but pathogenic agents with clinical relevance are Klebsiella pneumoniae isolated from persons with infectious pneumonia and Staphylococcus aureus mainly detected in deep wound infections, both are the main bacteria associated with $80 \%$ of nosocomial cases (RHOVE, 2009).

The resistance to the antibiotics is the natural response of microbial survival front a selective pressure such as conventional antibiotics. From the anthropocentric point of view, also, it's a continuous competition between the microbial survival and its control, maybe, with novel molecules of plant origin. Often, by means of ethnomedical and ethnobotanical knowledge and the phytochemical search is obtaining novel molecules with antibacterial activities. In this regard, the chemical study the plant species that are successful colonizers, particularly those used in traditional medicine and native to the Michoacan territory, appear to be promissory as sources of bioactive molecules (Damian Badillo et al., 2008).

A search in national and local herbarium found that in this region the Tribe Eupatorieae is present and its plant genera are abundant (Ramírez López, et al., 2010; García Sánchez, et al., 2011). The tribe
Eupatorieae comprises about 1200 species mainly distributed in tropical America. Some of them species have medicinal properties which are used to relieve ailments of infections, some are weeds and are associated with disturbed ecosystems (Rzedowski and Calderón, 2005; Guilherme et al., 2002; Katinas et al., 2007; Navarro et al., 2003). Therefore, the importance is greater in the case of a genus that groups important species in traditional medicine of several societies in five continents, in South America and Asia they are used to relieve maladies associated with signs and symptoms of microbial and parasitic infection (Ramírez López et al., 2010).

The importance of Eupatorium spp. in Mexican traditional medicine is given by the use of thirteen medicinal plants distributed in several ethnic pharmacopeias (García Sánchez et al., 2011). They are: E. albicaule, E. areolare, E. arsenei, E. aschenbornianum, E. daleoides, E. glabratum, E. morifolium, E. odoratum, E. petiolare, E. pulchellum, E. pycnocephalum, E. quadrangulare and E. squarrosum. With the exception of $E$. daleoides the rest of species have been reported as plant natives of Michoacan but not all of them are used as medicinal plants. However, some of them by their medicinal properties both for ancestral as modern medical practices and scarce o null chemical studies are in focus such as $E$. areolare, $E$. arsenei, $E$. glabratum and E. pulchellum: they are plants that successfully spread in this region of the world. Their use is to relieve pain, in addition to gastrointestinal, respiratory, and renal disorders associated with bacterial infections (Magaña et al., 2010). Few pharmacological studies have been done to corroborate their biological actions 
due to scarce phytochemical information. Also, in other Mexican cultures they are used with the same purpose; E. areolare (borreguillo) is used by the Maya-Chontal culture, E. arsenei (falso Tabardillo), E. glabratum (Chamizo, Jesus deni) is used in the Otomi culture and E. pulchellum are used in traditional medicine Purepecha culture (i.e. oral lore).

Although there is phytochemistry information about bioactive components in the Tribe Eupatorieae, there remain many species native and endemic to explore by their bioactive components. An exciting field to phytochemical exploration biodirected is generated (Ramírez López et al., 2010). The phytochemical investigation of medicinal plants is explored. All the species are used in different Mexican ethnic groups and cultures to treat symptoms associated with bacterial infections. This study was conducted for to do a chemical exploration into of the plant extracts from E. areolare, E. arsenei, E. glabratum, and E. pulchellum that affect the growth of nosocomial bacterial isolates that exhibit an important resistance to conventional antibiotics.

\section{RESULTS AND DISCUSSION}

\section{Antibacterial activity}

Thirty six samples arising from hexane, dichloromethane, and methanol extracts were screened against four Gram positive and nine Gram negative resistant bacteria associated with nosocomial infections, by disk diffusion method. Wild microbial isolated were identified by biochemical tests and their antibiotic resistance were determinate, see table 1 . The effect of plant extracts on bacterial growth is variable as a function of the group's bacteria, plant extract, and type of effect. The zones of inhibition ranged from 1 to $20 \mathrm{~mm}$ in diameter.

Plant extracts are grouped to discriminate those that would have a prominent antibacterial effect and the most sensitive bacterium. Antibacterial activity of medicinal plant extracts, which increased in the following order: hexane, dichloromethane and methanol. The correspondence analysis displayed three groups. In the group 1 are located plant extracts that affect the growth of Gram negative bacteria. They were the dichloromethane and methanol extracts from E. arsenei and E. pulchellum. As well as hexane extracts of $E$. areolare. These extract exhibited antibacterial activity against C. freundii, E. coli, E. cloacae, K. pneumoniae, $P$. mirabilis, $P$. aeruginosa, Proteus vulgaris, Salmonella $\mathrm{sp}$, and $S$. sonnei. The isolated Gram negative bacteria were most resistant than Gram positive bacteria to the plant extracts tested. In group 2 are included the plant extracts that affect the growth of B. subtilis and found some hexane extracts. In group 3, the plant extracts that affect the growth of Staphylococcus, such as, $S$. aureus, S. epidermidis, S. saprohyticus. The hexane extracts from E. areolare, E. glabratum and $E$. pulchellum are the most effective to inhibit the bacterial growth (fig. 1).

The hexane extracts from four medicinal plants showing antibacterial components. In order of importance the best antibacterial effects is observe in hexane $>$ dichloromethane $>$ methanol plant extracts. Also, it notes that the Gram positive bacteria are more sensitive to the plant extracts tested. Our results with hexane extracts are consistent with the observation of non-polar extracts of E. ayapana and E. glandulosum 


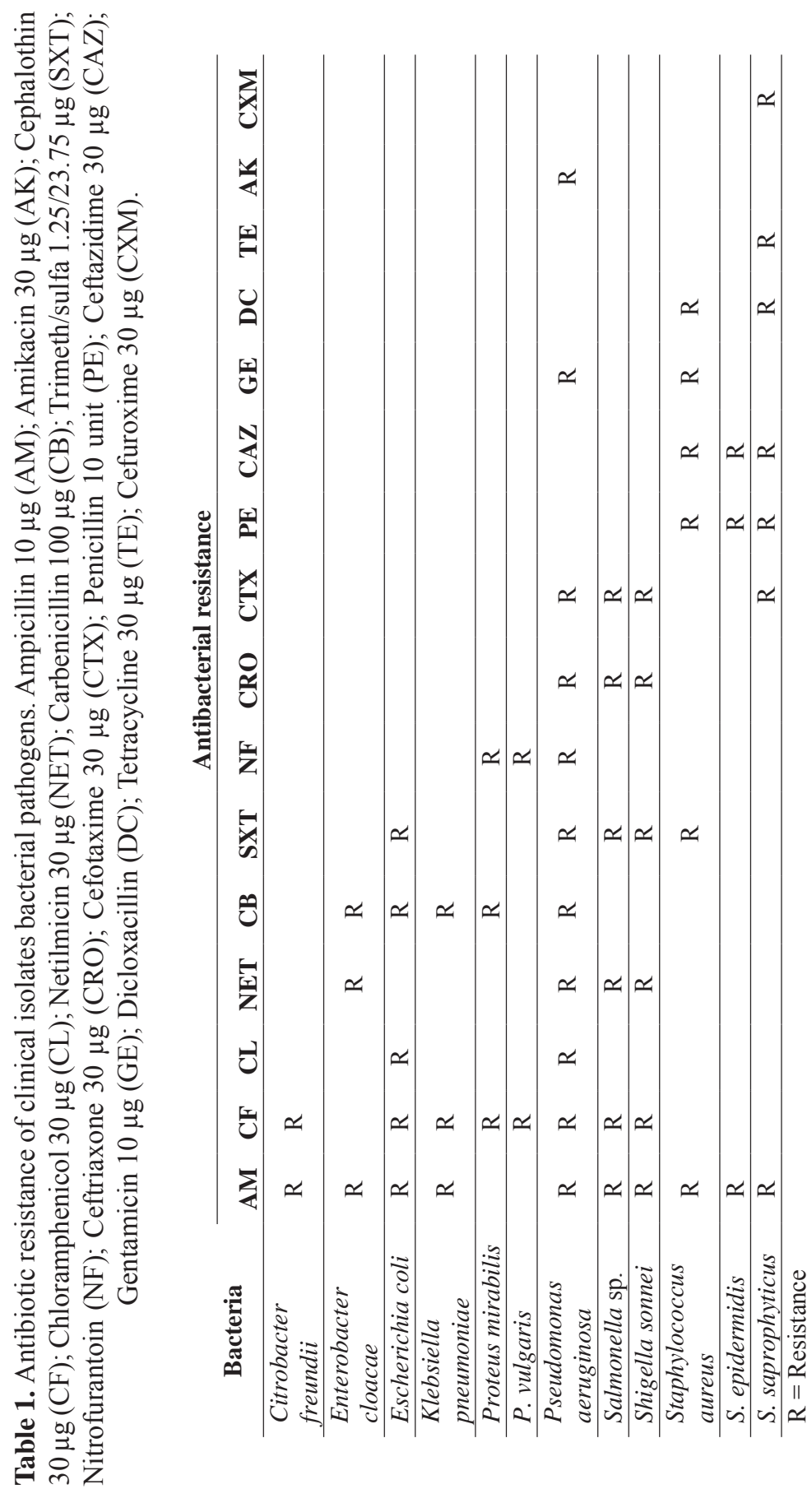




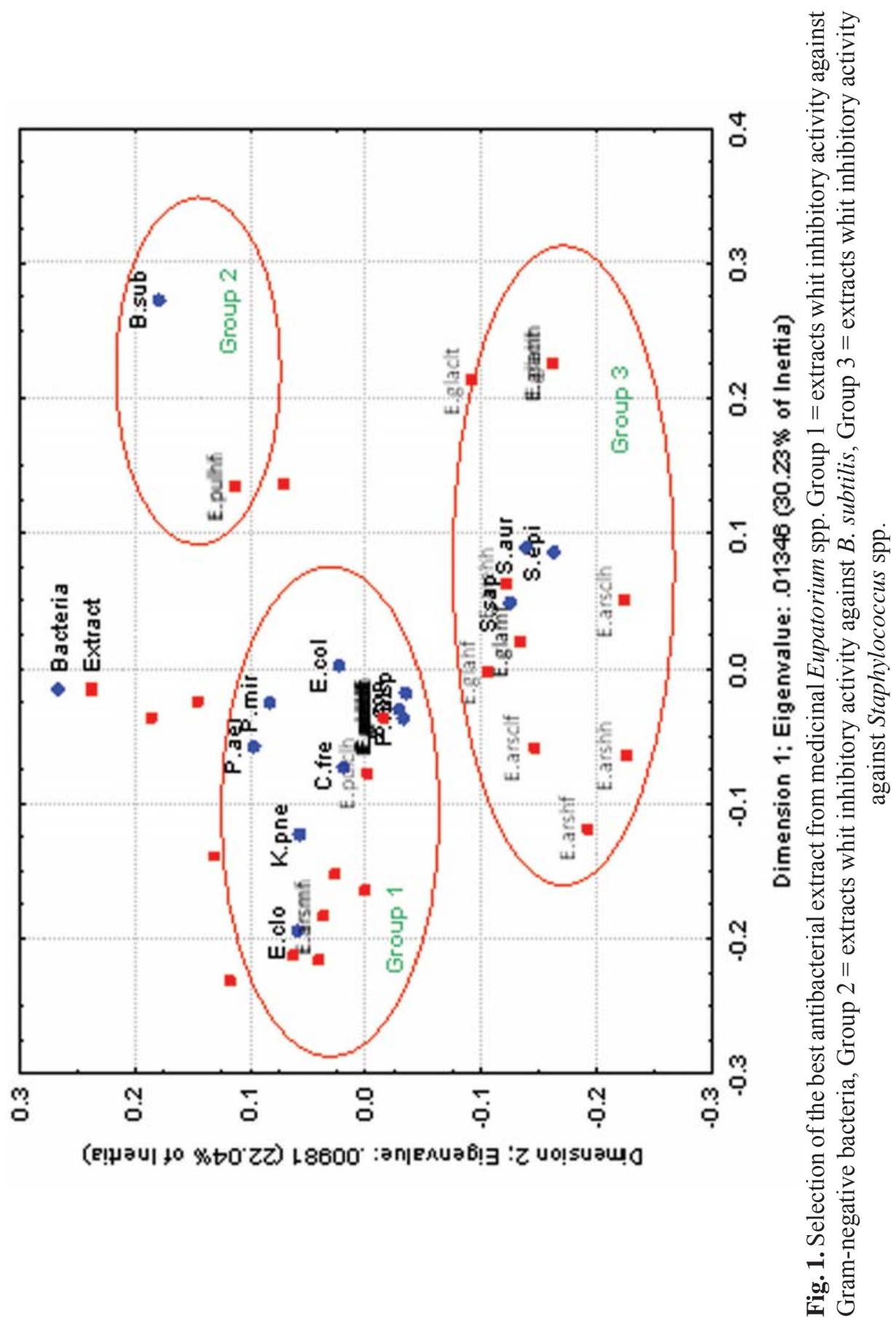


that inhibited the growth of Gram positive bacteria, all of them human pathogens (Sasikumar et al., 2005). As well as, it was reported that hexane extracts of leaves and stems of E. glutinosum affected the growth of two Gram positive and two Gram negative (El-Seedi et al., 2002).

\section{Qualitative chemical analysis of antibac- terial extracts}

The NMR spectra of antibacterial extract from E. areolare and E. glabratum showing signals characteristic of triterpenes. The major signals observed were located between $\delta 5.36$ and 5.12; also, $\delta 4.69$ and 4.45. These signals are representative of the vinylic hydrogen atoms and exocyclic methylene group. Moreover, were observed signals located between $\delta 2.0$ and 0.8 common signals of triterpenes. The qualitative chemical analysis of non-polar extracts from $E$. pulchellum leaves showing the presence of terpene-type components. However, the main signals of active extract from $E$. arsene $i$ were detected between $\delta$ 7.0 and 6.5; as well, $\delta 3.7$. These signals are typical of the hydrogen aromatic atoms and methoxyl group. Also, exhibited signal at aliphatic region $\delta 2.6-0.8$ distinctive signal of these compounds.

The phytochemical knowledge of these species is scarce. In $E$. arsenei have been identified a chromene compound (GarcíaVelgara, 1996). In E. glabratum (chamizo) has been reported eleven thymol derivatives, a flavone (acacetin) and eupaglabric acid (Guerrero et al., 1978; Bohlmann et al., 1997; García et al., 2011). In E. pulchellum has been identifying type pyrrolyzin alkaloids. It is infer that some of these plant metabolites are responsible for the observed antibacterial effect (Gómez-Hurtado et al., 2011). Also, it is known that $E$. areolare (borreguillo) have the following main compounds: sesquiterpenlactones, cinnamic acid, germacranolides and thymol derivatives (Hernández et al., 1986).

The plant extracts exhibited antibacterial effect against two of thirteen clinically important bacteria tested, they are K. pneumoniae and $S$. aureus. For these bacteria, it is observed low values of MICs when are treated with hexane and methylenic chloride extracts from E. pulchellum leaves. However, the main components identified in hexane extracts from $E$. areolare, $E$. arsenei, and E. glabratum have also been reported to have antibacterial activity in many medicinal plants (Abreu et al., 2011; Kiplimo et al., 2011). As well, benzopyran composites have been indentified major compounds in essential oils and extracts plants with remarkable activity antibacterial (Patil et al., 2010; Satoh et al., 1996; Mihailovic et al., 2011).

Our results showing that medicinal Eupatorium species studied in this work present metabolites secondary antibacterial and validate their uses in folkloric medicine. As well, motivates us to continue the study to find a compound responsible for the antibacterial activity. These results suggest that we should revised and extended phytochemical screening of these species with a new experimental design and with robust electronic infrastructure.

The need for new molecules effective to control of human pathogen bacteria given by high incidence of resistant strains, the medicinal plant species of the genus Eupatorium that we report are promising for the 
identification of molecules with antibacterial effect with emphasis special on those affecting the survival of two pathogenic bacteria involved in nosocomial infections; $K$. pneumoniae and S. aureus.

\section{EXPERIMENTAL}

\section{General}

${ }^{1} \mathrm{HNMR}$ spectra were recorded at $300 \mathrm{MHz}$ on a Varian Mercury 300 spectrometer using $\mathrm{CDCl}_{3}$ as solvent and tetramethylsilane (TMS) as internal reference; chemical shift values are reported in $\delta$ scale.

\section{Plant material}

Eupatorium areolare (E.are) [Piptothrix areolare (DC.) King \& Rob., Ageratina areolaris (DC.) Gage] (Voucher number 04135), E. arsenei (E.ars) [Ageratina arsenei (Rob.) King \& Rob] (voucher number 04143), E. glabratum (E.gla) [Ageratina glabrata (H.B.K.) King \& Rob] (Voucher number 04204) and E. pulchellum (E.pul) [Chromolaena pulchella (H.B.K.) King \& Rob.] (Voucher number 04330). All of them were collected between October and March (2006-2007) near at Morelia, Mich., the collecting area was done into circle at $200 \mathrm{~km}$ diameter with reference point is $19^{\circ}$ $39.938^{\prime} \mathrm{N}$ and $101^{\circ} 00.300^{\prime} \mathrm{W}$., the interval of 2069 to 2304 m.a.s.1.

They were taxonomically determined by the botanist, retaining a specimen in the herbarium of the Instituto de Ecología de Pátzcuaro and one more in the Instituto de Investigaciones Químico Biológicas at the Universidad Michoacana de San Nicolás de Hidalgo.

\section{Elaboration of extracts}

Leaf (105 g), flower (285 g), stem (310 g) from $E$. arsenei; leaf (155 g), flower (135 $\mathrm{g})$, stem $(1,229 \mathrm{~g})$ from $E$. areolare; leaf (225 g), flower (90 g), stem (625 g) from E. glabratum; and leaf (120 g), flower (355 $\mathrm{g})$, stem (260 g) from E. pulchellum were macerated with hexane, dichloromethane, and methanol at room temperature $(3 \mathrm{x}$ $1.5 \mathrm{~L})$. Extractions yield are leaf $(4.36 \%)$, flower $(10.75 \%)$, stem $(3.38 \%)$ and root $(1.28 \%)$. We performed column chromatography of leaf extract (2 g), flower (1 g) and stem (2 g).

\section{Used bacteria}

The bacteria tested were biochemically characterized and their antibiotic resistance (table 1). The wild Gram-negative and Gram-positive bacteria and ATCC bacteria used were obtained from Laboratorio Estatal de Salud Pública, Michoacán, Mexico.

\section{Antibacterial test}

Antibacterial test was carried out by the disc diffusion method. It was performed using an $18 \mathrm{~h}$ culture growth at $37^{\circ} \mathrm{C}$ with $10^{6} \mathrm{CFU} / \mathrm{ml}$. The inoculums were spread over plates containing Mueller-Hinton agar and paper filter disc $(6 \mathrm{~mm})$ impregnated with the extracts $1 \mathrm{mg} / \mu \mathrm{l}$, the plates were incubated at $37^{\circ} \mathrm{C}$ for $18 \mathrm{~h}$. At the end of the period, the inhibition zone around the disc was measured. Two controls were also included in the test, the first, was a positive control (cefotamixime $0.125 \mathrm{mg} / \mu \mathrm{l}$ ) and a negative control ethanol $96 \%(0.8 \mathrm{mg} / \mu \mathrm{l})$. 


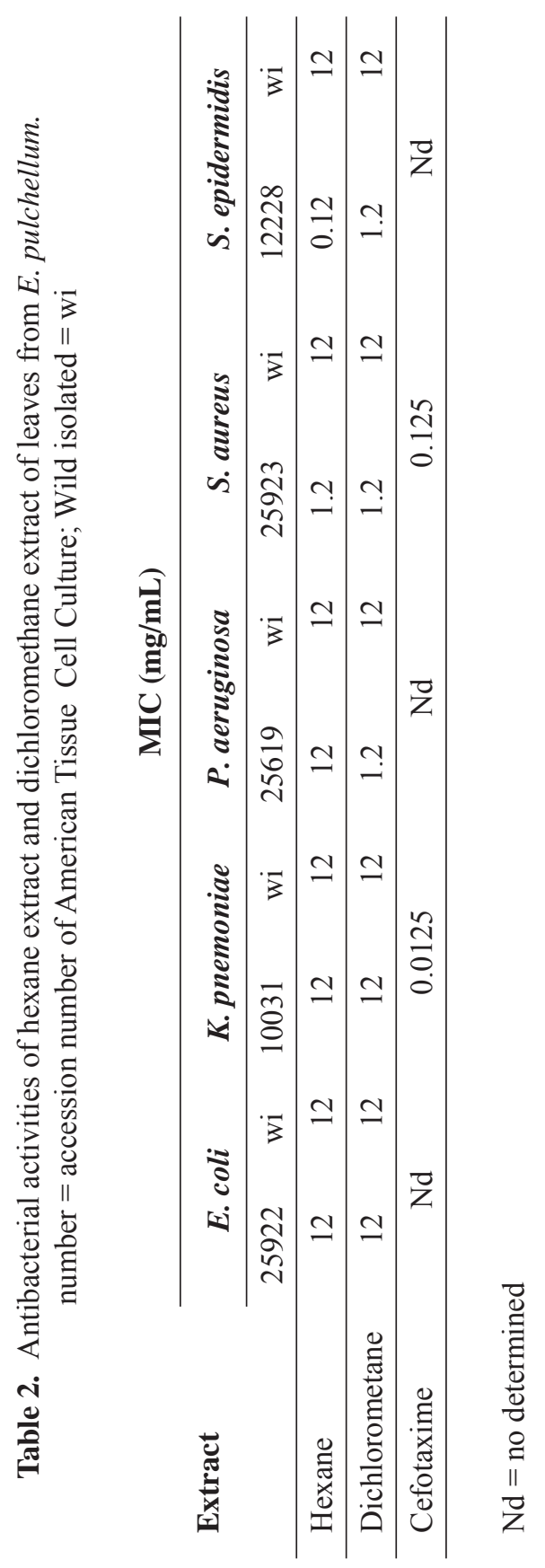




\section{Data analysis}

Experiments were evaluated by correspondence analysis (CA) to visualize the between variables. CA was carried out in two dimensions. The first dimension makes discrimination on bacteria and the second dimension on vegetal extract. We analyzed 13 rows and 72 columns with a total of 936 observations. The matrix was built in Excel program, considering bactericidal (bc) or bacteriostatic (bt) effect, Gram positive/Gram negative bacterial, zone inhibition of each plant extract and each bacterial isolate.

\section{CONCLUSIONS}

Medicinal Eupatorium spp. exhibited antibacterial activity against antibiotic resistance strains specifically against $K$. pneumoniae and $S$. aureus. This work showed four examples the importance of following up leads from Michoacan traditional medicine. These results contribute to the knowledge of the secondary metabolites of species growing in Michoacan State and validate the medicinal uses of the plants in folkloric medicine.

\section{ACKNOWLEDGEMENTS}

The authors thank USMNH and CECTI funding this work. EGS and CBRL are fellows of CONACYT. Also, to Jerzy Rzedoswzki Botanist from Instituto of Ecología A.C., Campus Pátzcuaro, Mich.

\section{LITERATURE CITED}

Abreu, V.; J. Takahashi, L. Duarte, D. PiloVeloso, P. Junior, R.O. Alves, A.J. Romanha, y A.F.C. Alcántara, 2011.
"Evaluation of the bactericidal and trypanocidal activities of triterpenes isolated from the leaves, stems and flowers of Lychnophora pinaster". Braz. J. Pharmacogn, 21: 615-621.

Bohlmann, F.; J. Jakupovic, y M. Lonitz, 1977. "Über inhaltsstoffe der Eupatorium-Gruppe"; Chem. Ber., 110: 301-314.

Damian-Badillo, L.M.; R.M. Espinosa Madrigal, R.E. Martínez Muñoz, O.A. Ron Echeverria, R. Salgado Garciglia; A. Flores García; D. Raya González; y M.M. Martínez Pacheco, 2008. "The mexican medical plants with antifungal properties are an economic and health opportunity area". Pharmacology Online, 3: 61-77.

El-Seedi, H.R.; T. Ohara, N. Sata, y S. Nishiyama, 2002. "Antimicrobial diterpenoids from Eupatorium glutinosum (Asteraceae)". J. Ethnopharmacol., 81: 293-296.

García-Sánchez, E.; C.B. Ramírez López, R.E.N. del Río, y M.M. Martínez Pacheco, 2011. "A revision of Eupatorium (Compositae: Eupatorieae) from Michoacan”. Phyton, 80: 4-11.

García, P.G.; T.R.E.N. del Río, M.R. Guzmán, G. Ma. I. Martínez, y R.F.T. Scior, 2011. "Preliminary studies on the analgesic effect of leaf extract from Ageratina glabrata in two thermal models of acute pain". Rev. Mex. Cienc. Farmaceut., 42: 22-28.

García-Velgara, M., 1996. "Estudio Químico de la parte aérea de Bursera cuneata 
y Eupatorium arsenei". Tesis de licenciatura. Instituto de Investigaciones Químico Biológicas. Universidad Michoacana de San Nicolás de Hidalgo, Michoacán, México.

Gómez-Hurtado, M.A.; J.M. Torres-Valencia, J. Manríquez-Torres, R.E. del Río, V. Motilva, S. García-Mauriño, J. Ávila, E. Talero, C.M. Cerda-García-Rojas, y P. Joseph-Nathan, 2011. "Absolute configuration of labdanes and ent-clerodanes from Chromolaena pulchella by vibrational circular dichroism". Phytochemistry, $\mathbf{7 2}$ : 409-414.

Guerrero, C.; M. Silva, E. Maldonado, y M. Martínez, 1978. "Eupaglabric acid a new compound isolated from Eupatorium glabratum H.B.K.". Rev. Latinoamer. Quim., 9: 71-75.

Guilherme, S.M.J.; B.Z.M. das Gracas, A.A.E. Helena, L.S.M. Helio, R.L.A. Iran, y J. Domingos, 2002. "Essential oils composition of Eupatorium species growing wild in the Amazon". Biochem. Syst. Ecol., 30: 1071-1077.

Hernández, J.D.; L.U. Román, M.J. Rodríguez, J. Espiñeira, y P. Joseph-Nathan, 1986. "Areolal, a thymol from Piptotrix areolare". Phytochemistry, 25: 1743-1744.

Katinas, L.; D.G. Gutierrez, M.A. Grossi, y J.V. Crisci, 2007. "Panorama de la Familia Asteraceae (= Compositae) en la República Argentina". Bol. Soc. Argent. Bot., 42: 113-129.
Kiplimo, J.; N.A. Koorbanally, y H. Chenia, 2011. "Triterpenoids from Vernonia auriculifera Hiern exhibit antimicrobial activity". Afr. J. Pharm. Pharmacol., 5: 1150-1156.

Magaña, A.M.A.; C.L.Ma. Gama, y M.R. Mariaca, 2010. "El uso de las plantas medicinales en las comunidades MayaChontales de Nacajunca, Tabasco, México". Polibotánica, 29: 213-262.

Mihailovic, V.; N. Vukovic, N. Niciforovic, S. Solujic, M. Mladenovic, P. Maskovic, y M. Stankovic, 2011. "Studies on the antimicrobial activity and chemical of the essential oils and alcoholic extracts of Gentiana asclepiadea L". J. Med. Plant Res., 5: 1164-1174.

Navarro, G.V.M.; A. González, M. Fuentes, M. Aviles, M.Y. Ríos, G. Zepeda, y M.G. Rojas, 2003. "Antifungal activities of nine traditional Mexican medicinal plants". J. Ethnopharmacol., 87: 85-88.

Patil, R.P.; M. Nimbalkar, U. Jadhav, V. Dawkar, y S. Govindwar, 2010. "Antiaflatoxigenic and antioxidant activity of an essential oil from Ageratum conyzoides L". Journal Sci. Food Agric., 90: 608-614.

Ramírez-López, C.B.; E. García Sánchez, A. León Hernández, D. Raya González, R.E. del Río, A. Flores García, y M.M. Martínez Pacheco, 2010. "Phytochemical perspective of Eupatorium spp". Pharmacology Online, 3: 682-690. 
García-Sánchez, E. et al.: Antibacterial activity of some Eupatorium species against antibiotic resistant pathogenic bacteria

RHOVE, 2009. Red Hospitalaria de Vigilancia Epidemiológica, de Sistema Nacional de Vigilancia Epidemiológica. Secretaría de Salud. www.rhove. gob.mx

Rzedowski, J., y G.Rzedowski, 2005. “Tribu Eupatorieae". Flora fanerogámica del Valle de México. $2 \mathrm{da}$. ed., Instituto de Ecología, A.C. Centro Regional del Bajío, Comisión Nacional para el Conocimiento y Uso de la Biodiversidad, México, pp. 781-800.
Sasikumar, J.M.; A.A.D. Pichai; y A. Doss, 2005. Antibacterial activity of Eupatorium glandulosum leaves. Fitoterapia, 70: 240-243.

Satoh, A.; H. Utamura, M. Ishizuka, N. Endo, M. Tsuji, y H. Nishimura, 1996. "Antimicrobial benzopyrans from the receptacle of sunflower". Biosci. Biotechnol. Biochem., 60: 664-665.

Recibido: 13 agosto 2013. Aceptado: 12 junio 2014. 